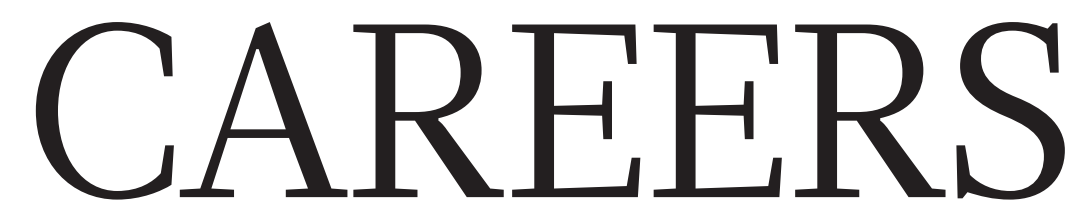

FUNDING How to find, save and manage cash in the lab go.nature.com/2x486cg
MoBILITY Tips on how to move to another lab go.nature.com/31uahcu
ONLINE Career resources from our community at nature.com/careers

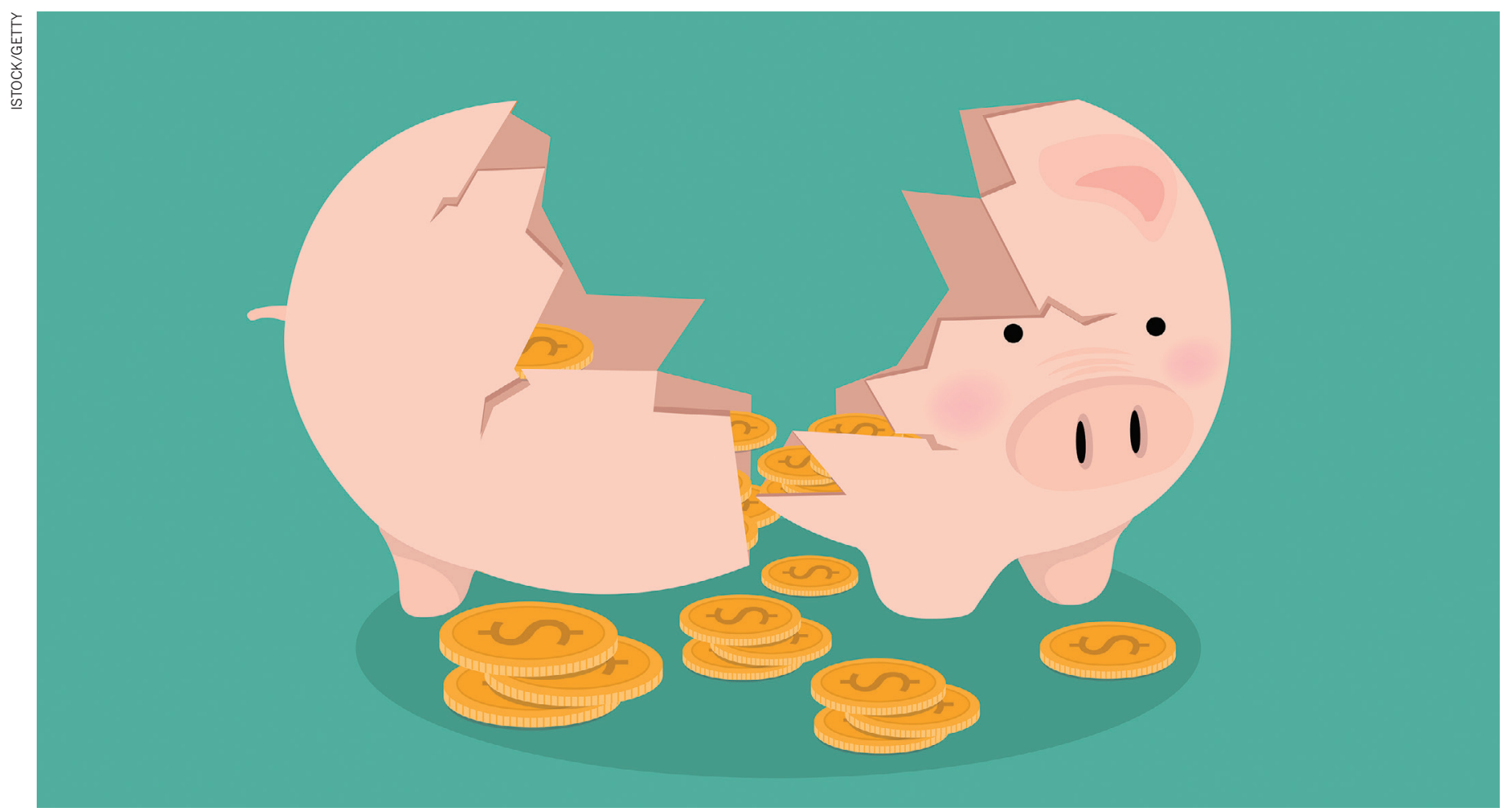

\title{
On the move
}

\section{Early-career researchers often bear the burden of paying relocation expenses.}

\section{BY ROBERTA KWOK}

I n July 2018, Scott Jones received an offer of a postdoc position at the United States Geological Survey (USGS) Western Ecological Research Center in Davis, California. Jones, a plant ecologist, had just completed his $\mathrm{PhD}$ at the University of Louisiana at Lafayette and was working for the Louisiana Universities Marine Consortium in Chauvin on a three-month contract. But his excitement about landing a longer-term position turned to worry when he learned that the USGS would not reimburse relocation expenses for the 3,600-kilometre move.

Jones and his wife had two children and were expecting a third. During his postgraduate studies, Jones had earned US\$20,000-27,000 per year from a fellowship and teaching. He and his wife had around $\$ 145,000$ of undergraduate student-loan debt, and towards the end of his
$\mathrm{PhD}$ programme, about one-third of his income had gone to loan repayments. The couple had saved $\$ 8,000$, but the move cost them almost $\$ 10,000$. Expenses included $\$ 2,300$ to ship their belongings; $\$ 700$ for petrol, lodgings and food to drive cross-country; $\$ 3,360$ to cover their first and last month's rent; a $\$ 600$ housing security deposit (as required by many landlords); and $\$ 1,500$ for car repairs to meet the State of California's smog-inspection requirements.

The USGS generally does not pay relocation expenses for short-term positions, and such assistance is not provided automatically for permanent positions, says Keith Miles, director of the USGS Western Ecological Research Center in Sacramento, California. The agency must justify the use of taxpayers' money for relocations, and USGS managers consider many factors in their decision-making, including the quality of local candidates and time constraints for filling the position, he says.
Jones put about $\$ 2,000$ of expenses that he could not pay up front on a credit card. $\mathrm{He}$ started his new job in September, and received his first salary payment three weeks later. But in December and January, the US federal government shut down for 35 days; as a furloughed employee (put on temporary leave), Jones was not allowed to come into work, and his pay was suspended. He and his wife paid off the creditcard balance in March, which included about $\$ 100$ in interest.

When Jones tweeted about his financial situation in September, he received responses from many other researchers who had also struggled to pay work-related moving expenses. "I was absolutely shocked," he says.

Although some institutions offer relocation assistance for postdocs and $\mathrm{PhD}$ students, policies vary widely (see 'Relocation assistance'). Paying for moving expenses can be stressful for junior scientists because they are often $>$ 
> financially unstable, and those who are relocating to an area with a higher cost of living might be particularly hard-pressed. International moves can present extra hurdles such as visa fees and poor exchange rates. Yet many researchers swallow the costs to seize career opportunities, even when that means emptying savings accounts, borrowing money from family and friends or even racking up creditcard debt.

Jones suggests that if institutions, funding agencies or principal investigators (PIs) do not pay at least some relocation expenses for geographically distant $\mathrm{PhD}$ students and postdocs, they are forcing out scientists who lack the money to cover a long-distance move. Although Jones is a first-generation university student, he notes that, as a white man, he was fortunate not to have faced further systemic barriers. The struggle can be even more acute for junior researchers who have encountered obstacles such as gender or racial bias - which could, for instance, have resulted in lower wages and therefore less savings, he says.

"The system is broken," Jones says. "If we're not providing moving expenses, we're phasing people out."

\section{OFF THE RADAR}

Interviews with financial advisers, university administrators and researchers suggest that although faculty members and industry employees often get relocation assistance, such support is patchy for postdocs and $\mathrm{PhD}$ students. Reimbursement is commonly made to senior staff members in academia because institutions have worked hard to recruit outstanding candidates and want to ease the transition, says Justin Zobel, pro-vice-chancellor of graduate and international research at the University of Melbourne, Australia. Postdoc positions can be so competitive that employers don't have to offer as many benefits, he says.

Many administrators or PIs might not think about providing relocation assistance because they didn't get such benefits themselves, says Gary McDowell, who is based in San Francisco, California, as executive director of the non-profit organization Future of Research, which advocates for junior researchers. "It's probably not on most people's radar," he says. And the mentality across much of academia, he says, is that one must suffer to succeed.

Institutions and PIs might also be reluctant to pay for a postdoc's relocation because the researcher is joining them for only a short time, says Eric Lofgren, an infectious-disease epidemiologist at Washington State University in Pullman. But the itinerant lifestyle of a postdoc is one reason that help should be offered to them, he says. "They're entering a point in their lives where academia, as it is set up, is going to ask them to move a whole bunch." Lofgren used $\$ 1,500$ of unallocated lab start-up funds to help his first postdoc to move from West Virginia to Washington in 2018. He plans to offer similar support to future postdocs, partly because Pullman is in a remote location and has a tight rental market, which means that people might need to stay in temporary accommodation while searching for housing.

PIs can include moving expenses for $\mathrm{PhD}$ students and postdocs in grant budgets if funding agencies allow it, Jones notes. But, "Ultimately, it's the institution or the department's responsibility," he says. Lofgren agrees that, in an ideal world, departments would pay for $\mathrm{PhD}$ students' relocation. However, "Most departments just may not have the budget," he says. Some institutions do assist graduate students; for example, recipients of university-level graduate research scholarships at the University of Melbourne can request relocation grants, Zobel says.

Computational biologist Koustav Pal received support from his institution when he moved from New Delhi, India, to Milan, Italy, in December 2014 to enter a $\mathrm{PhD}$ programme at the FIRC Institute of Molecular Oncology (IFOM). The institution paid about $€ 1,350$ $(\$ 1,500)$ for his relocation. That amount covered his $€ 700$ flight from India, $€ 100$ for document translation and the validation of his degrees by a government-authorized agency, and $€ 300$ for winter clothing; he did not ship any belongings. IFOM provided free lodging while Pal looked for an apartment, and its staff members negotiated with his new landlord to enable Pal to pay the security deposit in two instalments, which reduced his upfront housing expenses from $€ 1,500$ to $€ 1,000$. Although Pal had enough savings to cover those costs, the Indian rupee's exchange rate with the euro was poor. Paying outlays from his salary in euros was therefore "a dream", says Pal, who is now a postdoc at IFOM.

IFOM helps with moving expenses for all PhD students, postdocs and research staff members, says Elena Bauer, communications manager at the institute. The temporary free lodging and housing-negotiation assistance 


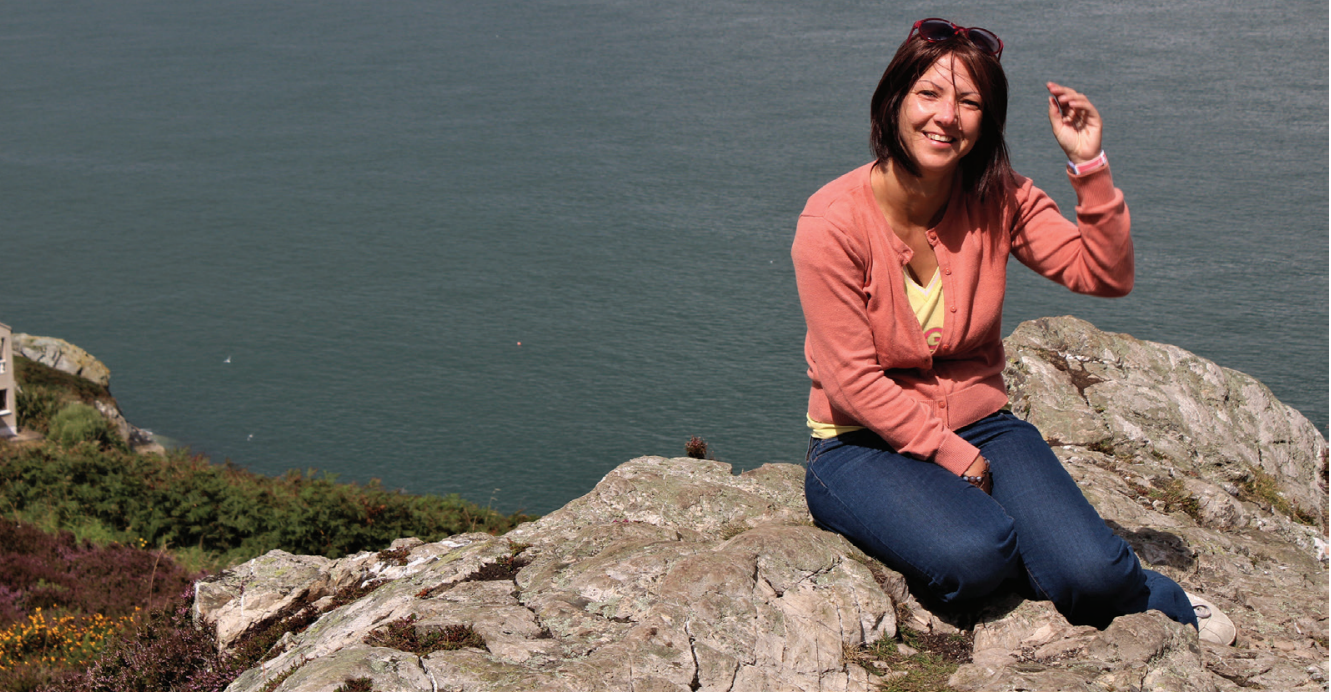

Geophysicist Lavinia Tunini had just enough savings to cover the move to her second postdoc position.

that Pal received are also standard benefits.

Relocation assistance for early-career researchers might improve as graduate schools try to increase student diversity. Last year, the University of Michigan Medical School in Ann Arbor started to pay a $\$ 1,000$ moving stipend to all students joining its $\mathrm{PhD}$ programme in biomedical sciences, including those from abroad; the amount will increase to $\$ 2,500$ this year. The assistance was added to boost recruitment and to be inclusive of students who are less privileged financially, says Scott Barolo, the programme's director. Filipe Cerqueira, a PhD student in microbiology and immunology, entered the programme before the stipend was enacted and had to get a student loan that accrued interest to cover the cost of relocating from Texas to Michigan. He tweeted in April that policies such as the moving stipend were "key to recruiting brown people" into predominantly white institutions.

Some financial advisers and scientists recommend negotiating with administrators or prospective PIs. "You don't know what they can offer you until you ask," Jones says. Junior researchers should estimate the volume of their belongings, get quotes from moving or truckrental companies, look up petrol or flight prices, and budget for on-the-road expenses such as accommodation and food, says Kate Mielitz, a financial counsellor at Oklahoma State University in Stillwater. Early-career scientists should express their excitement about the position, tell the administrator or PI what they estimate their relocation expenses will be and then ask for a specific amount to help fund their move, Mielitz suggests.

Delaying the move can reduce costs. Archaeologist Hugh Thomas was working in Sydney as a sessional lecturer and consultant when he received an offer in January 2018 for a research-fellow position at the University of Western Australia, almost 4,000 kilometres away in Perth. The contract was for slightly less than two years, and his new employer offered several thousands of Australian dollars towards relocation, which came from the privately funded project's budget, but it was not enough to cover all of Thomas's moving costs.

The University of Western Australia covers relocation expenses for employees who are appointed for two or more years, unless the position is research-funded, in which case a discretionary amount might be provided, says David Stacey, a university spokesperson. For staff members who are appointed for less than two years, funds are allocated up to certain limits, Stacey says.

Because his wife was due to give birth soon, Thomas asked to work remotely for up to six months. This buffer provided them with time to tighten their budget and to research hotel prices along the 41-hour driving route to Perth. The couple also monitored rental properties online and flagged those that lingered on the market, reasoning that their landlords might be amenable to negotiation. The strategy paid off: Thomas negotiated down the rent on their chosen property by about Aus $\$ 200$ (US\$140) per month, which helped to reduce upfront housing costs.

The family still had to pay about Aus $\$ 8,000$ in non-reimbursable expenses for moving and securing housing. But that amount could have been substantially higher if they had needed to relocate immediately, Thomas says. Although he asked to work remotely because of his child's impending birth, other researchers could make the same request to minimize moving expenses, he suggests.

\section{SALARY GAPS}

Even when an employer is able to reimburse expenses, the money might not arrive until several months after a scientist has started their new position, says Emily Roberts, founder of financial-education company Personal Finance for PhDs in Seattle, Washington. To avoid paying interest on credit-card balances, researchers need cash, she says. $\mathrm{PhD}$ students who anticipate moving for a postdoc should start saving when they begin their postgraduate programme, if possible, Mielitz says.

Despite forethought, researchers sometimes have to drain savings to cover periods of unemployment and salary delays. Geophysicist Lavinia Tunini saved about $€ 14,000$ during her $\mathrm{PhD}$ programme and first postdoc in Barcelona, Spain, in 2011-17. But she spent about $€ 8,000$ on living expenses between positions, which left her with only $€ 6,000$ when she moved to Paris for a second postdoc, at the École Normale Supérieure (ENS) in November 2017. Tunini rented a temporary room while searching for a permanent flat; after two months, she found one that required $€ 4,000$ to secure. Because of bureaucratic obstacles, she had not yet received a full salary payment, and her remaining savings were just enough to cover the costs.

Delays in the first month's salary payment are "absolutely unacceptable, and we are working hard to avoid those types of situations", says Laurent Bopp, director of the geosciences department at ENS. He notes that such delays generally arise only when the institution wants to start the contract as soon as possible, so that the postdoc doesn't have to wait to begin work. The ENS usually does not reimburse moving expenses for $\mathrm{PhD}$ students and postdocs, but the academic system in France offers benefits such as health-care coverage, a retirement plan and a $50 \%$ reimbursement of local commuting costs, Bopp says. Members of faculty and staff are not reimbursed for relocation expenses either, in accordance with rules for public-service employees, but have guaranteed employment for life, he says.

Researchers who must pay moving costs can minimize expenses by planning the move a couple of months in advance, Roberts says. Scientists can post advertisements to sell belongings and obtain free or cheap packing materials through sites such as Craigslist or Buy Nothing Project groups on Facebook. Jones and his wife asked friends on social media whether they knew anyone with whom the family could stay during their cross-country drive; in total, they paid only about $\$ 150$ for lodgings.

If a scientist doesn't have enough savings, Roberts suggests getting a personal loan from a bank, which typically carries a lower interest rate than does a credit card (with the exception of $0 \%$ interest promotional offers). Some people borrow money on interest-free terms from family or friends. While Jones was paying off his credit-card debt, his family got one free meal per month at a local church; during the government shutdown, they accepted three free meals per week from organizations that mainly served homeless people. It felt "uncomfortable", he says, but accepting support was necessary to survive the financial struggle.

Institutions should be the ones to provide help, McDowell says. "A couple thousand dollars shouldn't be the barrier to attracting good researchers to your institution if you genuinely are invested in supporting them and their research," he says.

Roberta Kwok is a freelance writer in Kirkland, Washington. 